\title{
pH effect microbial corrosion of Corten steel and Carbon steel in oily waste water with Pseudomonas Aeruginosa
}

\author{
Hamidreza Mansouri ${ }^{1,2 *}$, Seyed Abolhasan Alavi ${ }^{1}$, Reza Javaherdashti ${ }^{3}$, Hossein \\ Esmaeili $^{2,4}$, Hamed Mansouri ${ }^{5}$, Asadollah Kariman ${ }^{6}$ \\ ${ }^{I}$ (Department of Chemical engineering, Science and Research Branch of Tehran, Islamic Azad University, \\ Tehran, Iran) \\ ${ }_{2}^{2}$ (Parsian Gas Refining company) \\ ${ }_{3}^{3}$ (Materials Technology Unit, Qatar University, Doha, Qatar) \\ ${ }^{4}$ (Department of Chemical engineering, Science and Research Branch of Fars, Islamic Azad University, Shiraz, \\ Iran) \\ ${ }^{5}$ (Department of Chemical engineering, Shiraz University, Shiraz, Iran) \\ ${ }^{6}$ (Department of Chemical engineering, Osmania University, Hyderabad, India)
}

\begin{abstract}
Microbial corrosion of Corten steel and Carbon steel in oily waste water is investigated in three different PH. Used culture is provided from natural oily waste water and Nutrient Broth culture. Then bacterium is inoculated to culture and electrochemical analyze is done after two weeks. Results show that biofilm doesn't form completely in acidic media, so in these media, medium affect steel directly. In addition, Corten steel has different behavior against bacteria in comparison with Carbon steel because of having $\mathrm{Cu}$ in its composition.
\end{abstract}

Keywords: - Microbial Corrosion, Pseudomonas Aeruginosa, Corten steel, Carbon Steel, Stainless steel

\section{INTRODUCTION}

Microbial corrosion is a serious problem in industries. Because it is costly and industries have to spend billions of dollars annual [1-3]. By using suitable materials and media not only corrosion but also the cost would be reduced. Microbial corrosion is an electrochemical process which needs to water and Nutrient for microorganisms [4-6].

The attachment of microorganisms onto firm surfaces (substrata) is a natural widespread phenomenon which is almost observed in boundaries between surfaces (which is exposed to an aqueous environment) in the form of biofilms. The living microorganisms in these biofilms are immobilized in a hydrated slime capsule. As a result of the secretion of extracellular polymeric substances (EPS) and its gel-like properties ensures the cohesion of the cellular biofilm components [7].

The petroleum production environment is partially suitable for bacteria, because it handles large volumes of free oxygen of the water, which usually contains all the required Nutrients to the growth of microorganism [8]. In the oil industry, pipelines and equipment are the most vulnerable facilities against microbial corrosion, because of the produced water, hydrostatic testing, and shutdowns [9].

Created pits by bacterial activity clarify localized microbial-influenced corrosion (MIC) in iron alloys [10-11] .

The localized pits are usually manifested by the presence of small deep corrosion pits that are covered with corrosion product [12].

Biofilms can influence metal surface in electrochemical processes and lead to the deterioration of metals. This phenomenon is related to biocorrosion or microbial influenced corrosion (MIC). Biofilms usually consist of microbial cells and their metabolic products (including extracellular polymers and inorganic precipitates). Metabolic products generate as a result of production or destruction via physical and chemical process of a microorganism [13-14].

Pseudomonas Aeruginosa bacteria can live in many places such as soil, water, plants, animals, humans, swimming pools, whirlpools, hot tubs. In addition, they can grow in distilled water. Pseudomonas Aeruginosa is a bacterium that can grow in places with low Nutrients. Pseudomonas Aeruginosa mainly lives in slime-enclosed biofilms [15].

Microbial influenced corrosion (MIC) doesn't occur in all media and its reason isn't still certain. Recent research indicates that quality of the water $(\mathrm{pH}$, hardness and Nutrient content) and the percent of $\mathrm{Cu}$ are influenced in microbial corrosion [16-18].

It is the first time, microbial corrosion in actual oily waste water was investigated. Corten steel as weathering steel in three different $\mathrm{pH}$ indicated considerable results. 


\section{EXPERIMENTAL}

\subsection{Materials}

2.1.1. Steel samples

Carbon steel A105 was chosen to compare with Corten steel because of its common use in gas and oil industries. In addition, Corten steel has anti-microbial and corrosion properties because of having $0.25 \% \mathrm{Cu}$ in its composition. The sample composition are given in table 1.

Table 1. Chemical composition of ASTM A105 carbon steel /AISI 316L SS / Corten steel used for the experiments.

\begin{tabular}{|c|c|c|c|c|c|c|c|c|c|c|}
\hline \multirow{2}{*}{ Classification } & \multicolumn{9}{|c|}{ Chemical Composition } \\
\cline { 2 - 21 } & $\mathrm{C}$ & $\mathrm{Si}$ & $\mathrm{Mn}$ & $\mathrm{P}$ & $\mathrm{S}$ & $\mathrm{Ni}$ & $\mathrm{Cr}$ & $\mathrm{Mo}$ & $\mathrm{Cu}$ & $\mathrm{v}$ \\
\hline Carbon steel & 0.21 & 0.25 & 1.06 & 0.011 & 0.016 & 0.03 & 0.06 & 0.02 & 0.02 & 0.002 \\
\hline Corten steel & .07 & 0.63 & 0.44 & 0.08 & $<0.003$ & 0.85 & 0.71 & 0.22 & 0.29 & 0.087 \\
\hline
\end{tabular}

Carbon steel and Corten steel coupons with size of $10 \mathrm{~mm} \times 10 \mathrm{~mm} \times 0.4 \mathrm{~mm}$ were used. The sample compositions are given in table 1 . The coupons are continuously ground with a series of grit $\mathrm{SiC}$ papers up to 1200 and are polished by using $0.3 \mu \mathrm{m}$ alumina powders. The polished coupons are first rinsed with deionized (DI) water, followed by degreasing with acetone, then are sterilized by immersion in $70 \%$ ethanol for $8 \mathrm{~h}$ and dried aseptically in air. Prepared samples are immediately exposed in order to test medium for all the corrosion experiments.

\subsubsection{Oily waste water}

A lot of water generated from oil and gas extraction process. Produced water includes heavy metals and minerals salt which causes many problems such as corrosion in refineries. Used water was provided from No.16 reservoir gas of Iranian Tabnak.

\subsubsection{Chemicals}

Cetrimaid Agar and Nutrient Broth were purchased from Merck (Germany) and the media were prepared with oily waste water.

2.2. Apparatus

All electrochemical experiments carried out using $\mu$ AUTOLAB type III under the software control of Nova Ver. 1.5 .

2.1.3. Bacteria Isolation:

The microorganism isolated by the method of serial dilutions of the sample and plate count in selective medium Cetrimide Agar (Merck) was used for isolation purposes. The plates were incubated at $30{ }^{\circ} \mathrm{C}$ for 48 hours. It was identified using morphological, biochemical and molecular analysis.

2.1.4. Media

All experiments were performed using natural fresh oily waste water (O.W) that had collected from No. 16 reservoir gas of Iranian Tabnak oil field. In these samples, there was no significant $\mathrm{H}_{2} \mathrm{~S}$ after extraction so was ignored corrosion by $\mathrm{H}_{2} \mathrm{~S}$ and the real microbial corrosion was measurable. The extracted oily waste water from Sweet gas reservoir has been chosen because of not having sulfate influences, so corrosion doesn't occur.

Abiotic medium, inoculated medium with Pseudomonas and mixed culture are provide in three different $\mathrm{pH}(6$, 7 and 7.5).

1. Abiotic medium: this medium consist of oily waste water and $2 \mathrm{gr} / \mathrm{Lit}$ Nutrient Broth which was autoclaved for $15 \mathrm{~min}$ at $121^{\circ} \mathrm{C}$.

2. Inoculated medium with pseudomonas: this medium consist of oily waste water and $2 \mathrm{gr} / \mathrm{Lit}$ Nutrient Broth which was incubated for $15 \mathrm{~min}$ at $121^{\circ} \mathrm{C}$ then was inoculated with Pseudomonas.

3. Mixed culture: this medium consist of oily waste water and $2 \mathrm{gr} / \mathrm{Lit}$ Nutrient Broth which was autoclaved for $15 \mathrm{~min}$ at $121^{\circ} \mathrm{C}$ then was inoculated with bacteria.

2.3. Electrochemical tests

The experiments were performed in a $100 \mathrm{~mL}$ reactor at standard condition, using a conventional three electrode electrochemical cell: a platinum auxiliary electrode, A105 Carbon steel/A 242 Corten Steel used as Working electrode and $\mathrm{Ag} / \mathrm{AgCl}$ as Reference electrode.

The linear sweep voltammetry (LSV) were studied in $14^{\text {th }}$ day by scanning the potential from $-300 \mathrm{mV}$ vs. OCP to $+300 \mathrm{mV}$ vs. OCP with scan rate $1 \mathrm{mVs}^{-1}$. 


\section{RESULTS}

Carbon steels:

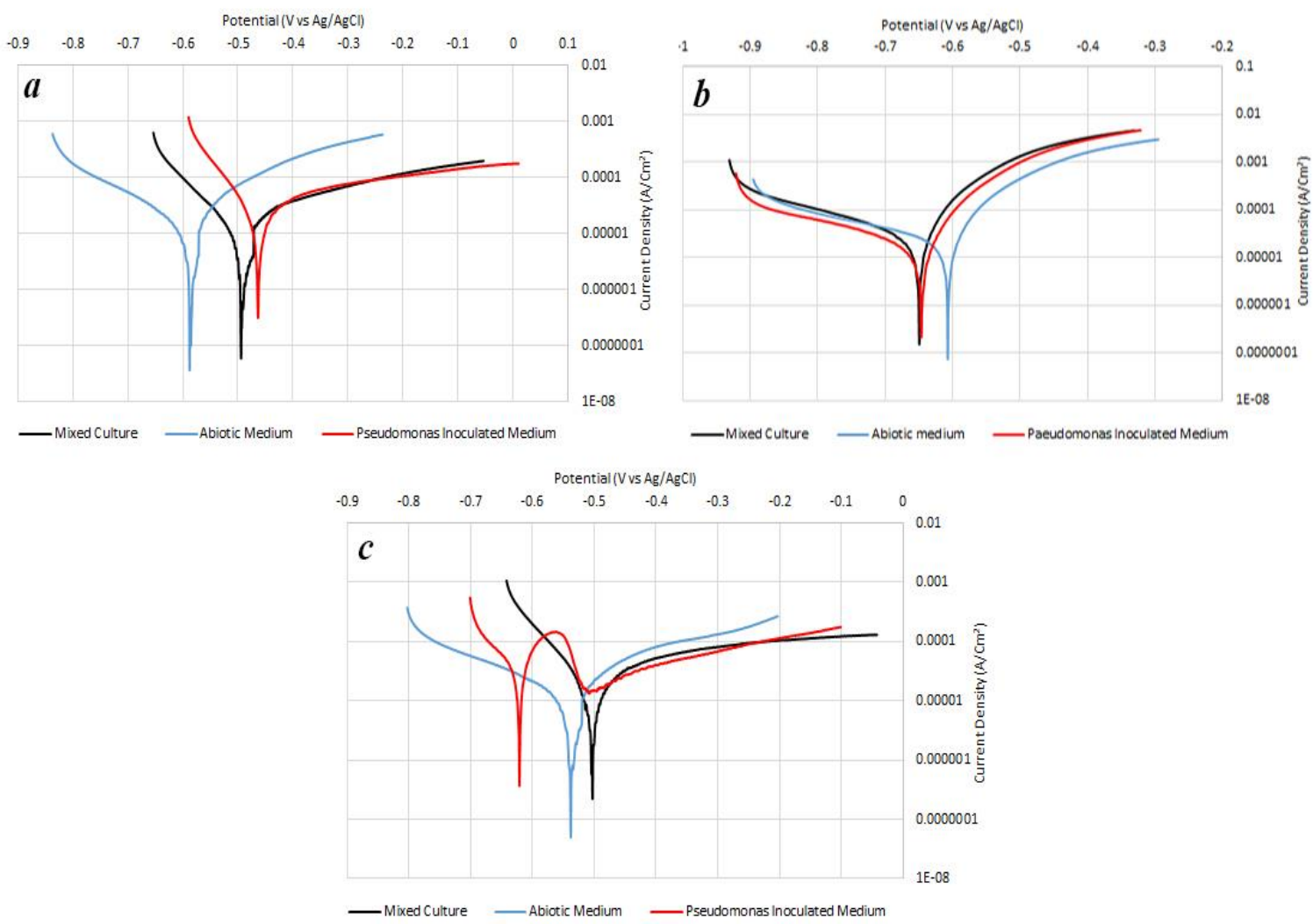

Fig 1. polarization curves of carbon steel immersed in medium with (a) $\mathrm{pH}=6$, (b) $\mathrm{pH}=7$, (c) $\mathrm{pH}=7.5$

Table 1. The corrosion parameter determined from carbon steel polarization curves.

\begin{tabular}{|c|c|c|c|c|c|}
\hline & & & \multirow[t]{2}{*}{$\mathrm{E}_{\text {corr }}(\mathrm{mV})$} & $\mathrm{i}_{\text {corr }}$ & \multirow[t]{2}{*}{$\begin{array}{l}\text { Polarization } \\
\text { resistance }(\Omega . \mathrm{cm})\end{array}$} \\
\hline & & & & $\left(\mathrm{A} / \mathrm{cm}^{2}\right)$ & \\
\hline \multirow{3}{*}{6.5} & Abiotic Medium & & -593 & $1.97 \mathrm{E}-05$ & 1909 \\
\hline & $\begin{array}{l}\text { Pseudomonas } \\
\text { Medium }\end{array}$ & Inoculated & -466 & $4.02 \mathrm{E}-05$ & 1024 \\
\hline & Mixed Culture & & -424 & $2.18 \mathrm{E}-05$ & 2077 \\
\hline \multirow{3}{*}{7} & Abiotic Medium & & -609 & $7.66 \mathrm{E}-05$ & 897.5 \\
\hline & $\begin{array}{l}\text { Pseudomonas } \\
\text { Medium }\end{array}$ & Inoculated & -647 & 2.79E-06 & 1289 \\
\hline & Mixed Culture & & -648 & $3.43 \mathrm{E}-05$ & 766.3 \\
\hline \multirow{3}{*}{7.5} & Abiotic Medium & & -534 & $5.47 \mathrm{E}-05$ & 2181.6 \\
\hline & $\begin{array}{l}\text { Pseudomonas } \\
\text { Medium }\end{array}$ & Inoculated & -622 & $1.94 \mathrm{E}-04$ & $3.53 \mathrm{E}+02$ \\
\hline & Mixed Culture & & -499 & $2.48 \mathrm{E}-05$ & $1.01 \mathrm{E}+06$ \\
\hline
\end{tabular}

Carbon steel was immersed in media with three different $\mathrm{pH}$ and was incubated for two weeks. Fig 1 is shown the polarization curves of them. Parameters of the fig 1 are given in table 1. Fig 1 (a) and dependent values on table 1 show more corrosion rate in abiotic medium in comparison with biotic mediums, because in biotic medium biofilms are formed so biofilms limit corrosion under acidic influence. In addition, more corrosion by mixed culture shows that some bacteria are involved by corrosion more than Pseudomonas Aeruginosa. Fig 1(b) shows that abiotic medium corrosion is less than biotic medium. It confirms the effect of 
the giant bacteria corrosion when $\mathrm{pH}=7$. Fig 1(c) emphasizes maximum corrosion rate by Pseudomonas Aeruginosa and minimum corrosion rate by Mixed Culture because of not contributing in MIC. These bacteria grow more than Pseudomonas Aeruginosa and limit corrosion.

In abiotic medium corrosion occurs because of acidification. By basification corrosion rate would be reduced. In media including Pseudomonas corrosion would be increased because of the growth of the microbes.

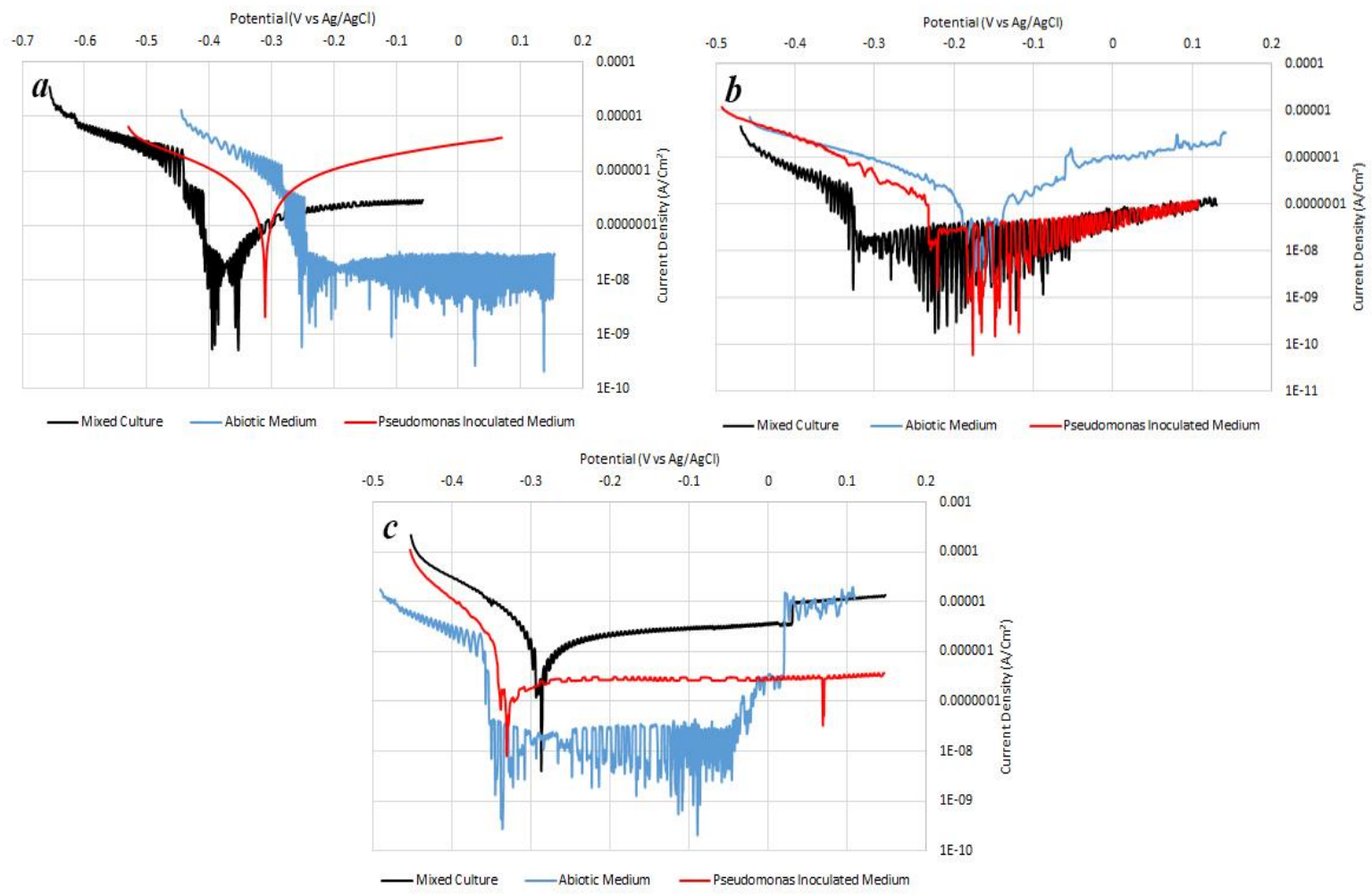

Fig 2. polarization curves of carbon steel immersed in medium with (a) $\mathrm{pH}=6$, (b) $\mathrm{pH}=7$, (c) $\mathrm{pH}=7.5$

Table 2. The corrosion parameter determined from carbon steel polarization curves.

\begin{tabular}{|c|c|c|c|c|c|}
\hline & & & $\mathrm{E}_{\text {corr }}(\mathrm{mV})$ & $\begin{array}{l}\mathrm{i}_{\text {corr }} \\
\left(\mathrm{A} / \mathrm{cm}^{2}\right)\end{array}$ & $\begin{array}{l}\text { Polarization } \\
\text { resistance } \\
(\Omega . \mathrm{cm})\end{array}$ \\
\hline \multirow{3}{*}{6.5} & Abiotic Medium & & -251 & $1.15 \mathrm{E}+00$ & 5802800 \\
\hline & $\begin{array}{l}\text { Pseudomonas } \\
\text { Medium }\end{array}$ & Inoculated & -312 & 9.29E-07 & 94631 \\
\hline & Mixed Culture & & -387 & $2.62 \mathrm{E}-08$ & 745110 \\
\hline \multirow{3}{*}{7} & Abiotic Medium & & -176 & $47.94 \mathrm{E}-.09$ & $3.15 E+05$ \\
\hline & $\begin{array}{l}\text { Pseudomonas } \\
\text { Medium }\end{array}$ & Inoculated & -220 & $15.880 \mathrm{E}-.09$ & $2.31 \mathrm{E}+06$ \\
\hline & Mixed Culture & & -312 & 9850E-.6 & $1.37 \mathrm{E}+06$ \\
\hline \multirow{3}{*}{7.5} & Abiotic Medium & & -281 & $3.6429 \mathrm{E}-.08$ & 502750 \\
\hline & $\begin{array}{l}\text { Pseudomonas } \\
\text { Medium }\end{array}$ & Inoculated & -311 & $6.54 \mathrm{E}-08$ & $4.01 \mathrm{E}+04$ \\
\hline & Mixed Culture & & -289 & 8.72E-08 & $1.42 \mathrm{E}+05$ \\
\hline
\end{tabular}


Fig 2 shows polarization curves after two weeks incubation in three different medium. Values of electrochemical test are shown in table 2. Fig 2 (a) and dependent values on table 2 show more corrosion by mixed culture. Because acidic media limit the growth of Pseudomonas Aeruginosa. Abiotic medium curve shows less corrosion rate because of Corten steel resistance against acidic media. Fig 2 (b) shows close corrosion rate value and less noise in abiotic medium. Biofilms act as electricity resistance and noises are create by biofilms. In abiotic medium biofilms don,t form completely so noise is less. Fig 2 (c) shows more corrosion rate by Pseudomonas inoculated medium. It confirms the limitation of the growth of some bacteria which are involved by corrosion more than Pseudomonas. $\mathrm{Cu}$ toxic property creates this limitation.

\section{CONCLUSION}

1. In acidic media corrosion effect by acidic $\mathrm{pH}$ is more than biofilm. Because the growth of microorganisms limits in these media.

2. Microorganisms protect of steel against corrosion in some condition. It proves that all bacteria have not impact on corrosion.

3. Corten steel resistance against corrosion was confirmed, so the use of Corten steel is suggested in media threathened by microbe.

\section{REFERENCES}

[1] S. E. Coetser,T. E. Cloete; Biofouling and Biocorrosion in Industrial Water Systems, Critical Reviews in Microbiology, 31(2005)213-232.

[2] Tingyue Gu, New Understandings of Biocorrosion Mechanisms and their Classifications, J Microbial Biochem Technol (2012) 4:4

[3] Iwona B Beech, Jan Sunner, Biocorrosion: towards understanding interactions between biofilms and metals,

[4] Reza Javaherdashtia, R.K. Singh Ramanb, C. Panterc, E.V. Perelomad, Microbiologically assisted stress corrosion cracking of carbon steel in mixed and pure cultures of sulfate reducing bacteria, Int. Biodeter. Biodegr. 58 (2006) 27-35

[5] Reza Javaherdashti, Impact of sulphate-reducing bacteria on the performance of engineering materials, Appl Microbiol Biotechnol, 91 (2011)1507-1517

[6] Reza Javaherdashti, Microbiologically influenced corrosion — an engineering insight, Springer, UK, 2008

[7] W. Sand, T. Gehrke, Microbially Influenced Corrosion of Steel in Aqueous Environments, Reviews in Environmental Science and Biotechnology, Volume 2, Issue 2-4, (2003) 169-176

[8] Kobrin, G.: In: Dexter S.C. (ed.) Proc. International Conference on Biological Induced Corrosion, National Association of Corrosion Engineers, Houston, TX (1986) 32.

[9] Failure Analysis and Prevention, vol. 11, 9th edn. Metals Handbook. ASM International, Materials Park, $\mathrm{OH}(2002)$.

[10] Michael J. Franklin, David C. White, Hugh S. Isaacs, Pitting corrosion by bacteria on carbon steel, determined by the scanning vibrating electrode technique, Corrosion Science, 32 (1991) 945-952

[11] R. C. Newman, W. P. Wong, and A. Garner (1986) Technical Note: A Mechanism of Microbial Pitting in Stainless Steel. Corrosion: August. 42 (1986)489-491

[12] During, E.D.D.: Corrosion Atlas. Elsevier Science, Amsterdam, The Netherlands (1997).

[13] David J. Beale a, *, Michael S. Dunn b, Donavan Marney a, Application of GC-MS metabolic profiling to 'blue-green water' from microbial influenced corrosion in copper pipes, Corrosion Science 52 (2010) 3140-3145

[14] C. Wittmann, Fluxome analysis using GC-MS, Microbial Cell Factories 6 (2007) 6.

[15] http://www.pseudomonas.com/p_aerug.jsp

[16] M. Critchley, R. Taylor, R. O'Halloran, Microbial contribution to blue water corrosion, Mater. Perform. 44 (2005) 56-59.

[17] M.M. Critchley, N.J. Cromar, N.C. McClure, H.J. Fallowfield, The influence of the chemical composition of drinking water on cuprosolvency by biofilm bacteria, J. Appl. Microbiol. 94 (2003) 501507.

[18] Beale, D, Dunn, M, Morrison, P, Porter, N and Marlow, Characterisation of bulk water samples from copper pipes undergoing microbially influenced corrosion by diagnostic metabolomics profiling, Corrosion Science, 55(2012) 272-279. 